\title{
Isolation and identification of Arcobacter species from environmental and drinking water samples
}

\author{
Funda Talay $^{1} \cdot$ Celenk Molva $^{2} \cdot$ Halil Ibrahim Atabay ${ }^{2,3}$
}

Received: 5 January 2016 / Accepted: 14 April 2016/Published online: 22 April 2016

(C) Institute of Microbiology, Academy of Sciences of the Czech Republic, v.v.i. 2016

\begin{abstract}
Water plays an important role in the transmission of Arcobacter spp. to animals and humans. The aim of this study was to isolate and characterize Arcobacter spp. from 115 different water samples (66 sewage, 25 rivers, 16 spring water, and 8 drinking water) in Izmir, Turkey. In total, 41 samples $(35.7 \%)$ were found positive for Arcobacter spp. by the genus-specific PCR. Arcobacter butzleri was detected in 39 out of 115 samples (33.9\%) including 24 sewage, 13 rivers, and 2 spring water. The remaining Arcobacter spp. $(n=2)$ isolates could not be identified by m-PCR and 16S rRNA gene sequencing. Based on the phenotypic characterization, most of the Arcobacter species $(87.8 \%)$ indicated weak catalase activity. In addition, there were differences in phenotypic patterns among isolated species during growth at $37{ }^{\circ} \mathrm{C}$ under microaerobic and aerobic conditions, in the presence of $2 \%(39 / 41)$ and $3.5 \%$ $(32 / 41) \mathrm{NaCl}$ and $0.04 \%$ TTC $(39 / 41)$ and on MacConkey agar (38/41). The results of this study indicated that environmental water samples are common sources for Arcobacter spp. Therefore, effective control measures should be taken to protect human health.
\end{abstract}

Halil Ibrahim Atabay

halil.atabay@sifa.edu.tr

1 Department of Bioengineering and Biotechnology, Izmir Institute of Technology, Urla 35430, Izmir, Turkey

2 Department of Food Engineering, Izmir Institute of Technology, Urla 35430, Izmir, Turkey

3 Department of Medical Microbiology, Faculty of Medicine, Sifa University, 35100 Izmir, Turkey

\section{Introduction}

The members of the genus Arcobacter are Gram-negative, fastidious, microaerophilic, non-spore-forming, usually motile, spiral-shaped organisms in the family of Campylobacteraceae. They differ from closely related campylobacters for their ability to grow microaerobically or aerobically at lower temperatures ranging from 15 to $37{ }^{\circ} \mathrm{C}$ (Vandamme and De Ley 1991). Although it is not a member of normal flora of human intestine, the consumption of contaminated foods of animal origin and water can result in human infections (Shah et al. 2011). Arcobacter spp. have been isolated from various sources such as water, foods of animal origin, clinical samples, food-processing equipment, and water distribution pipes (Phillips 2001). The genus Arcobacter currently includes 21 species (Giacometti et al. 2015). Among these species, Arcobacter butzleri, Arcobacter cryaerophilus, and Arcobacter skirrowii are the most important species due to their common association with human diseases (Ferreira et al. 2015). Clinical symptoms of Arcobacter infection are abdominal cramp and watery diarrhea (Collado and Figueras 2011).

Arcobacter prevalence has been detected in many countries. Understanding the potential risks related with this foodborne and waterborne pathogen is necessary (Hsu and Lee 2015). Since contaminated water is one of the possible sources of infection in animals and humans (Ho et al. 2006), to determine the prevalence of Arcobacter in water is useful to better understand the transmission process of these infectious agents, ecological characteristics, and zoonotic potential risks associated with water (Çelik and Ünver 2015). Wastewater (González et al. 2007; Collado et al. 2008; Merga et al. 2014), seawater (Collado et al. 2008; Fera et al. 2010; Ghane 2014), lakes and rivers (Collado et al. 2008; 2010), drinking water (Ertas et al. 2010; Jalava et al. 2014), groundwater (Fong et al. 2007), and recreational water (Lee et al. 
2012) were found positive for the presence of Arcobacter spp. Recently, there is limited information in terms of the prevalence of Arcobacter spp. in water from Turkey (Ertas et al. 2010; Çelik and Ünver 2015). Therefore, the present study was aimed to isolate and characterize Arcobacter spp. from different water sources using phenotypic and molecular methods in Izmir, Turkey.

\section{Material and methods}

\section{Bacterial strains}

Reference strains of A. butzleri (LMG 10828), A. cryaerophilus 1A (LMG 9904) and 1B (LMG 10229), and A. skirrowii (LMG 6621) were kindly provided by Maria José Figueras from University of Rovira I Virgili, Spain.

\section{Sample collection}

A total of 115 samples including sewage $(n=66)$, river $(n=25)$, spring water $(n=16)$, and drinking water $(n=8)$ were collected from 23 different sampling sites in Izmir and surrounding areas during a period of 7 weeks (February to April 2011). They were placed in separate sterile plastic bottles, transferred to the laboratory, and processed immediately.

\section{Isolation}

Briefly, $200 \mathrm{~mL}$ of sample was centrifuged at $3500 \mathrm{~g}$ for $15 \mathrm{~min}$. Then, the supernatant was discarded. The resulting pellet was suspended in $20 \mathrm{~mL}$ Arcobacter Broth (Oxoid CM965, UK) with CAT supplement (Cefoperazone, Teicoplanin, Amphotericin B, Oxoid SR174, UK). The broths were incubated under microaerophilic conditions using an automated anaerobic system (Anoxomat, Mart Microbiology, The Netherlands) at $30^{\circ} \mathrm{C}$ for 3 to 4 days. After enrichment, membrane filtration technique was applied using $0.45-\mu \mathrm{m}$ pore size nitrocellulose membrane filters (Millipore HAWG047S1, USA) as described previously (Atabay and Corry 1997). Briefly, $100 \mu \mathrm{L}$ of the enriched culture was pipetted onto the surface of membrane that had been placed onto the surface of blood agar base (Oxoid CM0055, UK) supplemented with $5 \%(v / v)$ sheep blood. After incubation at room temperature for $30 \mathrm{~min}$, the filters were carefully removed and discarded. Then, the filtrates were evenly distributed over the agar surface with a sterile spreader. Finally, the plates were incubated at $30{ }^{\circ} \mathrm{C}$ for $48-72 \mathrm{~h}$ under microaerobic conditions. Two to three suspected colonies (pin-pointed, translucent, and watery colonies) (Shah et al. 2012a) were selected from each plate and then subcultured by streaking on modified charcoal cefoperazone deoxycholate agar (mCCDA, Oxoid CM739, UK). Pure cultures were tested for Gram staining, oxidase test (Merck 1.13300, Germany), and motility under phase contrast microscope. Gram-negative, spiral-shaped, motile, and oxidase-positive isolates were stored in $20 \%(v / v)$ nutrient broth No. 2 (Oxoid CM0067, UK)-glycerol (AppliChem A1123, Germany) at $-80^{\circ} \mathrm{C}$.

\section{Phenotypic characterization}

The isolates were characterized phenotypically using methods as previously described (Atabay and Corry 1997; Atabay et al. 2008). These tests included catalase and $\mathrm{H}_{2} \mathrm{~S}$ production, indoxyl-acetate hydrolysis (Fluka 04739, UK), growth at different temperatures under aerobic and microaerobic conditions, and growth in the presence of $\mathrm{NaCl}(2$ and $3.5 \%, w / v$, AppliChem A1149, Germany) and $0.04 \%$ TTC (Oxoid SR0229, UK) and on MacConkey agar (Oxoid CM0007, UK).

\section{Genomic DNA isolation}

DNA was extracted using a commercial genomic DNA isolation kit (PureLink $®$ Kit, Invitrogen, Thermo Fisher Scientific, USA) according to the manufacturer's instructions. The concentration of each DNA was determined spectrophotometrically at 260 and $280 \mathrm{~nm}$ (NanoDrop 8000-Thermo Fisher Scientific, USA), adjusted to $20 \mathrm{ng} / \mu \mathrm{L}$ and stored at $-20^{\circ} \mathrm{C}$.

\section{Genus-specific PCR}

For the genus-specific PCR, the primer combinations ARCOIARCOII targeting a section of the 16S ribosomal RNA (rRNA) genes were used (Harmon and Wesley 1996). The PCR reactions were performed in a $25-\mu \mathrm{L}$ reaction mixture containing $2 \mu \mathrm{L}$ template DNA, $2.5 \mu \mathrm{L}$ of $10 \times$ PCR buffer, $3 \mathrm{mmol} / \mathrm{L} \mathrm{MgCl}_{2}, 10 \mu \mathrm{mol} / \mathrm{L}$ of each of the primers, $0.2 \mathrm{mmol} / \mathrm{L}$ each of the four dNTPs (Fermentas, Thermo Fisher Scientific, USA), and 1.5 U Taq DNA polymerase (Fermentas, Thermo Fisher Scientific, USA). The thermal cycling conditions were initial denaturation at $94{ }^{\circ} \mathrm{C}$ for $4 \mathrm{~min}$, followed by 29 cycles consisting of denaturation at $94{ }^{\circ} \mathrm{C}$ for $1 \mathrm{~min}$, annealing at $56^{\circ} \mathrm{C}$ for $1 \mathrm{~min}$, and primer extension at $72{ }^{\circ} \mathrm{C}$ for $1 \mathrm{~min}$. The final extension was performed at $72{ }^{\circ} \mathrm{C}$ for $7 \mathrm{~min}$. PCR experiments were repeated twice for each strain. The amplified products were electrophoresed on $1 \%$ $(w / v)$ Tris-acetate-EDTA (TAE, $0.04 \mathrm{~mol} / \mathrm{L}$ Tris-acetate, $0.001 \mathrm{~mol} / \mathrm{L}$ EDTA $\mathrm{pH}$ 8.0) agarose gel using $1 \mathrm{~kb}$ ladder (Fermentas, Thermo Fisher Scientific, USA). The band patterns were analyzed in a gel documentation system (Vilber Lourmat, France). The DNA of the reference strains were used as positive controls and sterile deionized water was used as a negative control in PCR experiments. 


\section{Multiplex PCR}

The isolates identified as Arcobacter spp. were examined by m-PCR using the primers developed by Houf et al. (2000). The selected primers amplify a 257-bp fragment from A. cryaerophilus, $401 \mathrm{bp}$ from A. butzleri, and $641 \mathrm{bp}$ fragment from A. skirrowii. PCR reactions were performed in a $25-\mu \mathrm{L}$ reaction mixture containing $2 \mu \mathrm{L}$ template DNA, $2.5 \mu \mathrm{L}$ of $10 \times \mathrm{PCR}$ buffer, $3 \mathrm{mmol} / \mathrm{L} \mathrm{MgCl} 2,10 \mu \mathrm{mol} / \mathrm{L}$ of each of the primers, $0.2 \mathrm{mmol} / \mathrm{L}$ each of the four dNTPs (Fermentas, Thermo Fisher Scientific, USA), and 1.5 U Taq DNA polymerase (Fermentas, Thermo Fisher Scientific, USA). The PCR reactions were performed in a thermal cycler Bio-Rad C-100 (Bio-Rad, USA) with the following amplification conditions: a denaturation step at $94{ }^{\circ} \mathrm{C}$ for $3 \mathrm{~min} ; 34$ amplification cycles: denaturation at $94^{\circ} \mathrm{C}$ for $30 \mathrm{~s}$, annealing at $60{ }^{\circ} \mathrm{C}$ for $30 \mathrm{~s}$, and extension at $72{ }^{\circ} \mathrm{C}$ for $1 \mathrm{~min}$; and the final extension step at $72{ }^{\circ} \mathrm{C}$ for $7 \mathrm{~min}$. The PCR products were analyzed on $1.25 \%(w / v)$ TAE-agarose gel using $100 \mathrm{bp}$ ladder (Fermentas, Thermo Fisher Scientific, USA). The band patterns were analyzed in the gel documentation system (Vilber Lourmat, France). DNA from reference strains and sterile deionized water were used as positive and negative controls, respectively.

\section{S ribosomal RNA gene sequencing}

The 16S rRNA genes were amplified using the same primers and conditions used for the genus-specific PCR (Harmon and Wesley 1996). After purification, the amplicons were sequenced bidirectionally using the same primers by the ABI 3130 XL genetic analyzer (Applied Biosystems, Thermo Fisher Scientific, USA) with the Prism BigDye terminator cycle sequencing kit (Applied Biosystems, Thermo Fisher Scientific, USA). Partial 16S rRNA sequences were compared with the other 16S rRNA gene sequences in GenBank database to determine their sequence identities.

\section{Results and discussion}

Water is an important source for the transmission of Arcobacter species to both animals and humans (Hsu and Lee 2015). In the present study, the occurrence of Arcobacter spp. was investigated in 115 water samples (66 sewage, 25 rivers, 16 spring water, and 8 drinking water samples) collected from Izmir, Turkey.

Sixty-one isolates that were Gram-negative, oxidase-positive, and indicating typical cork-screw type motility were subjected to genus-specific PCR. Since PCR amplification of campylobacters from water samples is difficult due to the low levels in the environmental samples, a short preenrichment followed by a purification step of the isolated genomic DNA is necessary before PCR analysis (Giesendorf et al. 1993; Van Camp et al. 1993). Therefore, the genomic DNA was extracted from pure cultures obtained after preenrichment step. Based on the genus-specific PCR, 41 out of 61 isolates were identified as Arcobacter spp. yielding a 1223bp fragment (Harmon and Wesley 1996). The overall prevalence of Arcobacter spp. in water was $35.7 \%$. Based on the type of sample, the prevalence was found as $52 \%(13 / 25)$ in river water, $36.4 \%(24 / 66)$ in sewage, and $25 \%(4 / 16)$ in spring water samples. Similar to a previous report from Kars, Turkey (Çelik and Ünver 2015), all drinking water samples were negative for Arcobacter spp. in this study most probably due to effective chlorination disinfection used for water treatment.

In the related literature, the prevalence of Arcobacter spp. has been reported in different water samples such as $23 \%$ in river and $100 \%$ in canal water (Morita et al. 2004); $55.1 \%$ in freshwater, seawater, and sewage samples (Collado et al. 2008); $3 \%$ in drinking water and $1 \%$ in spring water (Ertas et al. 2010); $75.2 \%$ in recreational water (Lee et al. 2012); $11.11 \%$ in chlorinated water (Shah et al. 2012a); $26.31 \%$ in creek water and $18.36 \%$ in stream water (Çelik and Ünver 2015); and $86.7 \%$ in wastewater (Šilha et al. 2015). The variations in the presence of arcobacters in water may be due to use of different sample types, fecal contamination levels, seasonal variations, water temperature, and isolation method used. Fong et al. (2007) suggested that extreme rainfall may provide in the transport of Arcobacter from wastewater treatment plants to groundwater. In another study, Lee et al. (2012) showed that the presence in recreational water was higher in September and the levels indicated a negative correlation with water temperature. It is known that Arcobacter spp. may survive better at lower temperatures in water (Fera et al. 2010). Also, the presence of Arcobacter spp. in water increases markedly with high levels of fecal contamination (Collado et al. 2008). As mentioned before, the method used for isolation may be effective on the recovery rates but there is no standardized protocol available for the isolation (Shah et al. 2012b). In this study, membrane filtration technique after selective enrichment in Arcobacter Broth with CAT supplement was used to eliminate the incidence of background flora. The use of selective supplement may lead to lower recovery rates of Arcobacter spp. in environmental water samples. Since the cells in environmental samples are stressed or injured, it has been reported that the use of inhibitory compounds may inhibit the growth of environmental isolates resulting in reduced recovery rates of injured cells of Campylobacter strains (Diergaardt et al. 2004).

The m-PCR indicated that $A$. butzleri was the only one recovered from $33.9 \%$ of the samples (Table 1). Previous studies have also showed that it is the most frequently associated species with water sources (Hsu and Lee 2015). In total, 21 samples including sewage $(n=13)$, river water $(n=7)$, and 
Table 1 Distribution of Arcobacter spp. in water based on the sample type and method used for species identification

\begin{tabular}{|c|c|c|c|c|c|}
\hline Source & No. of samples collected & No. of Arcobacter spp. & $\begin{array}{l}\text { No. of } A \text {. butzleri identified } \\
\text { by } \mathrm{m}-\mathrm{PCR}\end{array}$ & $\begin{array}{l}\text { No. of } A \text {. butzleri identified } \\
\text { by } 16 \mathrm{~S} \text { rRNA sequencing }\end{array}$ & Unidentified \\
\hline Sewage & 66 & $24(36.4 \%)$ & $13(19.7 \%)$ & $11(16.7 \%)$ & - \\
\hline River & 25 & $13(52 \%)$ & $7(28 \%)$ & $6(24 \%)$ & - \\
\hline Spring water & 16 & $4(25 \%)$ & $1(6.25 \%)$ & $1(6.25 \%)$ & $2(12.5 \%)$ \\
\hline Drinking water & 8 & - & - & - & - \\
\hline Total & 115 & $41(35.7 \%)$ & $21(18.3 \%)$ & $18(15.7 \%)$ & $2(1.74 \%)$ \\
\hline
\end{tabular}

spring water ( $n=1)$ were positive for A. butzleri by m-PCR. A high genetic diversity existing within the genus and also between the species has been observed (Collado et al. 2010; Kayman et al. 2012). The remaining Arcobacter species $(n=18)$ that were not identified with m-PCR were subjected to sequencing of $1223 \mathrm{bp}$ of fragment within the 16S rRNA gene. Based on sequencing, most of these isolates ( $n=18$ ) were assigned to A. butzleri with high level of similarities ranging from 96 to $99 \%$. These strains were obtained from sewage $(n=11)$, river water $(n=6)$, and spring water $(n=1)$. Two Arcobacter species from spring water could not be identified using m-PCR and sequencing (Table 1). The exact reasons for failure in identification of these isolates could be due to the lack of appropriate sequence of isolates and/or they could be a possible new strain/species.

The International Commission on Microbiological Specification for Foods (ICMSF 2002) has considered A. butzleri to be a significant hazard to human health. Interestingly, $63 \%$ of $A$. butzleri infections in humans occur mainly through consumption or close contact with contaminated water (Shah et al. 2011). A. butzleri can easily attach to water distribution pipe surfaces (stainless steel, copper, and plastic) which causes regrowth in the water distribution systems. Therefore, it is a significant problem in drinking water and food-processing plants with respect to public health (Assanta et al. 2002). In fact, the overall recovery rates of A. butzleri were $52 \%(13 / 25)$ in river water, followed by $36.4 \%(24 / 66)$ in sewage water and $12.5 \%(2 / 16)$ in spring water. In this study, sampling was done in the spring (February to April). These results were lower than those of the study conducted in Spain by Collado et al. (2010) in which A. butzleri was found more prevalent in sewage during spring (91.7 \%) and summer (83.3\%) in Spain. Ghane (2014) also reported that $A$. butzleri was predominant in the spring and summer in the Caspian Sea with an occurrence rate of 3.04 and $2.28 \%$, respectively.

A. butzleri was the only species identified in all sample types. In a recent study (Šilha et al. 2015), the most frequent isolated species in wastewater was A. cryaerophilus (38.1\%). Collado et al. (2008) isolated species of $A$. butzleri (94\%), followed by $A$. cryaerophilus (30\%) and A. skirrowii $(1.8 \%$ ) in environmental water samples. In another study, Morita et al. (2004) found that $A$. butzleri was the most frequent species isolated from river water samples in Japan and canal water samples in Thailand. Çelik and Ünver (2015) suggested that A. cryaerophilus and A. skirrowii may not be detected in environmental water or may be present under detection limit of methods due to the differences in ecological and biological characteristics of the organism. A. butzleri may indicate stronger viability than other species in water and may show competitive inhibitory effect on the other species present in population dynamic (Çelik and Ünver 2015).

As seen from Table 2, all Arcobacter species gave positive reaction for indoxyl-acetate hydrolysis and growth at $30{ }^{\circ} \mathrm{C}$

Table 2 The biochemical characteristics of Arcobacter spp. isolated from water samples

\begin{tabular}{|c|c|c|c|}
\hline & $\begin{array}{l}\text { A. butzleri } \\
\text { identified by } \\
\text { m-PCR } \\
(n=21)\end{array}$ & $\begin{array}{l}\text { A. butzleri } \\
\text { identified } \\
\text { by } 16 \mathrm{~S} \text { rRNA } \\
\text { sequencing } \\
(n=18)\end{array}$ & $\begin{array}{l}\text { Unidentified } \\
(n=2)\end{array}$ \\
\hline $\begin{array}{l}\text { Indoxyl-acetate } \\
\text { hydrolysis }\end{array}$ & 21 & 18 & 2 \\
\hline \multicolumn{4}{|l|}{ Catalase activity } \\
\hline Strong & 1 & 4 & - \\
\hline Weak & 20 & 14 & 2 \\
\hline $\mathrm{H}_{2} \mathrm{~S}$ production & - & - & - \\
\hline \multicolumn{4}{|l|}{ Microaerophilic at } \\
\hline $30^{\circ} \mathrm{C}$ & 21 & 18 & 2 \\
\hline $37^{\circ} \mathrm{C}$ & 19 & 13 & 2 \\
\hline $42{ }^{\circ} \mathrm{C}$ & 19 & 14 & 1 \\
\hline \multicolumn{4}{|l|}{ Aerobiosis at } \\
\hline $25^{\circ} \mathrm{C}$ & 21 & 18 & 2 \\
\hline $30{ }^{\circ} \mathrm{C}$ & 21 & 18 & 2 \\
\hline $37^{\circ} \mathrm{C}$ & 19 & 13 & 2 \\
\hline \multicolumn{4}{|l|}{ Growth in/on } \\
\hline $2 \%(w / v) \mathrm{NaCl}$ & 20 & 17 & 2 \\
\hline $3.5 \%(w / v) \mathrm{NaCl}$ & 14 & 16 & 2 \\
\hline $0.04 \%$ TTC & 19 & 18 & 2 \\
\hline MacConkey agar & 18 & 18 & 2 \\
\hline
\end{tabular}

TTC 2,3,5-triphenyltetrazolium chloride 
under microaerobic and aerobic conditions and at $25{ }^{\circ} \mathrm{C}$ during aerobic incubation and also failed in the production of $\mathrm{H}_{2} \mathrm{~S}$. Most Arcobacter species (87.8 \%) indicated weak catalase activity. On the other hand, they gave variable results during growth at $37{ }^{\circ} \mathrm{C}$ under both conditions. Also, there were differences in phenotypic patterns among species during growth in the presence of 2 and $3.5 \%(w / v) ~ N a C l$ and $0.04 \%$ TTC and on MacConkey agar (Table 2). In total, 39, 32, and 39 of the 41 isolates grew in the presence of 2 and $3.5 \% \mathrm{NaCl}$ and $0.04 \%$ TTC. And 38 strains were able to grow on MacConkey agar.

\section{Conclusions}

On the basis of the results of this study, it can be concluded that $A$. butzleri is a potential waterborne pathogen present in sewage, river, and spring water in Izmir. The presence of A. butzleri in the environmental water is of great importance for water quality and human health. Therefore, it is necessary to develop appropriate prevention and control strategies against $A$. butzleri in water sources to minimize public health risks.

Acknowledgments The authors thank the members of the Biotechnology and Bioengineering Research Center of Izmir Institute of Technology.

\section{References}

Assanta MA, Roy D, Lemay MJ, Montpetit D (2002) Attachment of Arcobacter butzleri, a new waterborne pathogen, to water distribution pipe surfaces. J Food Protect 65:1240-1247

Atabay HI, Corry JE (1997) The prevalence of Campylobacters and Arcobacters in broiler chickens. J Appl Microbiol 83:619-626

Atabay HI, Unver A, Sahin M, Otlu S, Elmali M, Yaman H (2008) Isolation of Arcobacter species from domestic geese (Anser anser). Vet Microbiol 128:400-405

Çelik E, Ünver A (2015) Isolation and identification of Arcobacter spp. by multiplex PCR from water sources in Kars region. Curr Microbiol 71:546-550

Collado L, Figueras MJ (2011) Taxonomy, epidemiology, and clinical relevance of the genus Arcobacter. Clin Microbiol Rev 24:174-192

Collado L, Inza I, Guarro J, Figueras MJ (2008) Presence of Arcobacter spp. in environmental waters correlates with high levels of fecal pollution. Environ Microbiol 10:1635-1640

Collado L, Kasimir G, Perez U, Bosch A, Pinto R, Saucedo G, Huguet JM, Figueras MJ (2010) Occurrence and diversity of Arcobacter spp. along the Llobregat River catchment, at sewage effluents and in a drinking water treatment plant. Water Res 44:3696-3702

Diergaardt SM, Venter SN, Spreeth A, Theron J, Brözel VS (2004) The occurrence of campylobacters in water sources in South Africa. Water Res 38:2589-2595

Ertas N, Dogruer Y, Gonulalan Z, Guner A, Ulger I (2010) Prevalence of Arcobacter species in drinking water, spring water, and raw milk as determined by multiplex PCR. J Food Prot 73:2099-2102
Fera MT, Gugliandolo C, Lentini V, Favaloro A, Bonanno D, La Camera E, Maugeri TL (2010) Specific detection of Arcobacter spp. in estuarine waters of Southern Italy by PCR and fluorescent in situ hybridization. Lett Appl Microbiol 50:65-70

Ferreira S, Queiroz JA, Oleastro M, Domingues FC (2015) Insights in the pathogenesis and resistance of Arcobacter: a review. Crit Rev Microbiol 25:1-20

Fong TT, Mansfield LS, Wilson DL, Schwab DJ, Molloy SL, Rose JB (2007) Massive microbiological groundwater contamination associated with a waterborne outbreak in Lake Erie, South Bass Island, Ohio. Environ Health Perspect 115:856-864

Ghane FGMM (2014) Isolation of Arcobacter butzleri from Caspian Sea's water. J Appl Environ Microbiol 2:61-64

Giacometti F, Salas-Mass N, Serraino A, Figueras MJ (2015) Characterization of Arcobacter suis isolated from water buffalo (Bubalus bubalis) milk. Food Microbiol 51:186-191

Giesendorf BAJ, van Belkum A, Koeken A, Stegeman H, Henkens MHC, van der Plas J, Goossens H, Niesters HGM, Quint WGV (1993) Development of species-specific DNA probes for Campylobacter jejuni, C. coli, and C. lari by polymerase chain reaction fingerprinting. J Clin Microbiol 31:1541-1546

González A, Botella S, Montes RM, Moreno Y, Ferrús MA (2007) Direct detection and identification of Arcobacter species by multiplex PCR in chicken and wastewater samples from Spain. J Food Protect 70: 341-347

Harmon KM, Wesley IV (1996) Identification of Arcobacter isolates by PCR. Lett Appl Microbiol 23:241-244

Ho HT, Lipman LJ, Gaastra W (2006) Arcobacter, what is known and unknown about a potential foodborne zoonotic agent! Vet Microbiol $115: 1-13$

Houf K, Tutenel A, De Zutter L, Van Hoof J, Vandamme P (2000) Development of a multiplex PCR assay for the simultaneous detection and identification of Arcobacter butzleri, Arcobacter cryaerophilus and Arcobacter skirrowii. FEMS Microbiol Lett 193:89-94

Hsu TT, Lee J (2015) Global distribution and prevalence of Arcobacter in food and water. Zoonoses Public Health 62:579-589

ICMSF (2002) Microorganisms in foods. 7. Microbiological testing in food safety management. international commission on microbiological specifications for foods. Kluwer Academic/Plenum Publishers, New York

Jalava K, Rintala H, Ollgren J, Maunula L, Gomez-Alvarez V, Revez J, Palander M, Antikainen J, Kauppinen A, Räsänen P, Siponen S, Nyholm O, Kyyhkynen A, Hakkarainen S, Merentie J, Pärnänen M, Loginov R, Ryu H, Kuusi M, Siitonen A, Miettinen I, Domingo JWS, Hänninen ML, Pitkänen T (2014) Novel microbiological and spatial statistical methods to improve strength of epidemiological evidence in a community-wide waterborne outbreak. PLoS One 9:e104713

Kayman T, Abay S, Hizlisoy H, Atabay HI, Diker KS, Aydin F (2012) Emerging pathogen Arcobacter spp. in acute gastroenteritis: molecular identification, antibiotic susceptibilities and genotyping of the isolated arcobacters. J Med Microbiol 61:1439-1444

Lee C, Agidi S, Marion JW, Lee J (2012) Arcobacter in Lake Erie beach waters: an emerging gastrointestinal pathogen linked with humanassociated fecal contamination. Appl Environ Microbiol 78:55115519

Merga JY, Royden A, Pandey AK, Williams NJ (2014) Arcobacter spp. isolated from untreated domestic effluent. Lett Appl Microbiol 59: $122-126$

Morita Y, Maruyama S, Kabeya H, Boonmar S, Imsuphan B, Nagai A, Kozawa K, Nakajima T, Mikami T, Kimura H (2004) Isolation and phylogenetic analysis of Arcobacter spp. in ground chicken meat and environmental water in Japan and Thailand. Microbiol Immunol 48:527-533 
Phillips CA (2001) Arcobacters as emerging human foodborne pathogens. Food Control 12:1-6

Shah AH, Saleha AA, Zunita Z, Murugaiyah M (2011) Arcobacter-an emerging threat to animals and animal origin food products? Trends Food Sci Technol 25:225-236

Shah AH, Saleha AA, Murugaiyah M, Zunita Z, Memon AA (2012a) Prevalence and distribution of Arcobacter spp. in raw milk and retail raw beef. J Food Prot 75:1474-1478

Shah AH, Saleha AA, Zunita Z, Cheah YK, Murugaiyah M, Korejo NA (2012b) Genetic characterization of Arcobacter isolates from various sources. Vet Microbiol 160:355-361
Šilha D, Šilhová-Hrušková L, Vytřasová J (2015) Modified isolation method of Arcobacter spp. from different environmental and food samples. Folia Microbiol 60:515-521

Van Camp G, Fierens H, Vandamme P, Goossens H, Huyghebaert A, De Wachter R (1993) Identification of enteropathogenic Campylobacter species by oligonucleotide probes and polymerase chain reaction based on 16S rRNA genes. Syst Appl Microbiol 16: $30-36$

Vandamme P, De Ley J (1991) Proposal for a new family, Campylobacteraceae. Int J Syst Bacteriol 41:451-455 